\title{
Impact of Age on Hormonal Profiles of Sub-Fertile Women Attending Fertility Clinic in Umuahia, Abia State, South Eastern Nigeria
}

\author{
Ebirien-Agana S. Bartimaeus ${ }^{*}$, Chukwuma E. J. Obi², Felix U. Igwe ${ }^{3}$, Edna 0. Nwachuku1 \\ ${ }^{1}$ Department of Medical Laboratory Science, Rivers State University, Nkpolu-Oroworukwo, Port Harcourt, Nigeria \\ ${ }^{2}$ Department of Medical Laboratory Services, Federal Medical Center, Umuahia, Abia State, Nigeria \\ ${ }^{3}$ Department of Biochemistry, Rivers State University, Nkpolu-Oroworukwo, Port Harcourt, Nigeria \\ Email: *ebbyagana@gmail.com
}

How to cite this paper: Bartimaeus, E.-A.S., Obi, C.E.J., Igwe, F.U. and Nwachuku, E.O. (2020) Impact of Age on Hormonal Profiles of Sub-Fertile Women Attending Fertility Clinic in Umuahia, Abia State, South Eastern Nigeria. Open Journal of Internal Medicine, 10, 51-68.

https://doi.org/10.4236/ojim.2020.101006

Received: January 13, 2020

Accepted: February 29, 2020

Published: March 3, 2020

Copyright (c) 2020 by author(s) and Scientific Research Publishing Inc. This work is licensed under the Creative Commons Attribution International License (CC BY 4.0).

http://creativecommons.org/licenses/by/4.0/

\begin{abstract}
Aim: This study evaluated the impact of age on the hormonal profiles of women diagnosed with infertility in a Fertility Clinic in Abia State, South-East, Nigeria. Methodology: Subjects comprised of 200 females: 150 subjects and 50 controls, aged $<20$ and up to 49 years, stratified into age $<20$ years (control), age 20 - 29 years (group 1), age 30 - 39 years (group 2) and age 40 - 49 years (group 3). About $5 \mathrm{ml}$ of blood samples for anti-Mullerian, follicle stimulating, luteinizing, estradiol, and prolactin hormones determinations were collected on day 2 - 3 of spontaneous menstrual cycle from all groups and control and analyzed using enzyme-linked immunosorbent assay. The FSH/LH ratio of all groups was also calculated. The data were analyzed statistically and values considered significant at $\mathrm{p}<0.05$. Result: The means \pm SEM of serum anti-Mullerian hormones were $1602.44 \pm 54.42 \mathrm{pg} / \mathrm{ml}$ (control), $848.06 \pm 23.04 \mathrm{pg} / \mathrm{ml}$ (group 1), $26.74 \pm 1.28 \mathrm{pg} / \mathrm{ml}$ (group 2), $10.37 \pm$ $1.26 \mathrm{pg} / \mathrm{ml}$ (group 3) values for follicle stimulating hormone in the control subjects was $4.90 \pm 0.22 \mathrm{mIU} / \mathrm{ml}, 12.59 \pm 0.79 \mathrm{mIU} / \mathrm{ml}$ (group 1), $30.59 \pm 1.31$ $\mathrm{mIU} / \mathrm{ml}$ (group 2), and $41.59 \pm 1.59 \mathrm{miU} / \mathrm{ml}$ (group 3). Similarly, the mean \pm SEM of luteinizing hormone of control, group 1, group 2 and group 3 were $5.01 \pm 0.22 \mathrm{mIU} / \mathrm{ml}, 15.02 \pm 1.13 \mathrm{mIU} / \mathrm{ml}, 42.71 \pm 1.82 \mathrm{mIU} / \mathrm{ml}$ and $58.22 \pm$ $2.62 \mathrm{mIU} / \mathrm{ml}$ respectively while for estadiol the values were $63.16 \pm 1.95$ $\mathrm{pg} / \mathrm{ml}, 94.10 \pm 5.56 \mathrm{pg} / \mathrm{ml}, 58.84 \pm 4.01 \mathrm{pg} / \mathrm{ml}$ and $36.7 \pm 1.59 \mathrm{pg} / \mathrm{ml}$ for control, group 1, group 2 and group 3 respectively. The mean \pm SEM of FSH/LH ratio for the control and experimental subjects were $0.98 \pm 0.01,0.89 \pm 0.02$, $0.74 \pm 0.03$ and $0.75 \pm 0.02$ for control, group 1 , group 2 and group 3 respectively. The comparison of the means showed significant difference $(\mathrm{p}<$ 0.0001 ). The hormonal parameters were also positively and negatively corre-
\end{abstract}


lated amongst each. Conclusion: The evaluation of levels of the hormonal parameters across the age ranges of the population studied shows that women within the control and experimental group 1 ( $<20$ years and $20-29$ years) have a better chance of achieving pregnancy naturally.

\section{Keywords}

Anti-Mullerian Hormone, Estradiol, Follicle Stimulating Hormone, Prolactin, Luteinizing Hormone

\section{Introduction}

Infertility is the inability of couples to accomplish conception or pregnancy after regular sexual intercourse for a period between one year and two years [1]. One of the main desires of couples in developing nations of the world is procreation [2]. Evidence shows that fertility is a major problem linked with reproductive health in sub-Saharan Africa [3]. As a result of poor documentation and lack of well-designed studies, an accurate prevalence of inability to be pregnant in developing countries has not been ascertained [4]. Many reports show that the inability to achieve pregnancy is one of the main reasons why couples visit gyneacological clinics in Nigeria [5] [6].

In developed nations of the world inability to achieve pregnancy has an average prevalence rate of $10 \%-15 \%$ [7] while in Sub-Saharan Africa, the prevalence rate of this reproductive condition ranges from $20 \%-46 \%$ [8]. In Nigeria, institution-based incidence of infertility as reported from some parts shows that South-Eastern Nigeria has a prevalence rate of $11.2 \%$ [9]. The effects of inability to be pregnant in Sub-Saharan Africa are tremendous; it could result to marital problems, divorce, depression, isolation, physical violence, stigmatization and economic hardship among others [10] [11].

Infertility can be primary or secondary, primary when the woman has never conceived and this has a prevalent range of $0.6 \%$ to $3.4 \%$ while secondary infertility is when the woman has achieved pregnancy before irrespective of the outcome with prevalent range of $8.7 \%$ to $32.6 \%$ [12]. About $37 \%$ of infertility is found in infertile couples [13]. For sometimes now, delay in childbearing has increased in our society. A good number of women also delay marriages and tend to get married and bear children at an advanced age. This is a common observation noticed among couples that visit reproductive clinics [14]. Nonetheless, the likelihood of these women to get pregnant starts to worsen later in their reproductive age. The occurrence of sub-fertility increases by $6 \%$ for age 20 to 24 years, $9 \%$ for age 25 to 29 years, $15 \%$ for age 30 to 34 years, $30 \%$ for age 35 to 39 years, and $64 \%$ for age 40 to 44 years [15]. Data obtained from natural population without contraception shows that fruitfulness from 35 years of age is decreased by half when compared with 25 years of age. In women, 35 years of age 
is believed to be the age when decrease in fruitfulness is clearly noticed [16].

Inability to be pregnant within a reproductive age in the absence of contraceptives is on the increase in our society today, and delay in childbearing, voluntary and involuntary is common among couples that visit fertility clinics. This phenomenon is on the increase in Nigeria, which calls for concern. Visits to fertility clinics across the country shows that the clinics are generally flooded with younger women who normally should be expected to bear children without any assisted means of reproduction. Based on the foregoing, this study was designed to evaluate the impact of age on the hormonal profiles of women diagnosed with infertility in a Fertility Clinic in Abia State, South-East, Nigeria.

\section{Materials and Methods}

\subsection{Description of Study Area}

Participants (patients) comprised of women who were attending the Fertility Clinic and the Assisted Reproductive Technology Unit (ART) of Federal Medical Centre, Umuahia. At first visit, general data for criteria eligibility were obtained through interviews and by using a structured questionnaire. Subjects (infertile) and controls (fertile) that fulfilled the inclusion and exclusion criteria were enrolled into the study. The nature of the study was clearly explained to the recruited participants (subjects and controls). They were all assured that the information gathered through the study would be kept confidential.

\subsection{Study Population}

The study consists of 200 females: 150 subjects and 50 controls, aged less than 20 and up to 49 years were considered and recruited for the study. The population of women studied was stratified into age $<20$ years which was used as the control (50 subjects), subjects in this group consists of relatively fertile women, age 20 - 29 years as group 1 (50 subjects), age 30 - 39 years as group 2 (50 subjects) and age $40-49$ years as group 3 of the experimental subjects ( 50 subjects).

\subsection{Ethical Approval}

The study was approved by the Research and Ethical Committee of the Federal Medical Centre, Umuahia, Abia State and each of the recruited participants gave an informed consent to participate in the study.

\subsection{Inclusive Criteria}

The studied population were subjects who were aged between 15 and 49 years of age, having unprotected sexual intercourse for a period of 1 year and above. The females used as control were relatively fertile women. Participants who were willing to participate in the study were non-pregnant women diagnosed with primary infertility. Those with oligo and or anovulation (defined by presence of oligomeorrhea or amenorrhea) and women with unexplained infertility were also included in the study. 


\subsection{Exclusive Criteria}

Exclusive criteria included women below the age of 15 years, with primary infertility with pure polycystic ovarian syndrome (PCOS), pelvic inflammatory diseases, endometriosis and other pelvic pathologies and those already on IVF treatment with donor's eggs were also excluded from the study.

\subsection{Experimental Design}

This is a case control-study, carried out among women attending the Fertility Clinic and the Assisted Reproductive Technology Unit (ART) of Federal Medical Centre, Umuahia, Abia State, South Eastern Nigeria. Information on age, duration of infertility, family history, menstrual flow, self-help measures, and other vital informations required for the study were obtained from the participants using a structured questionnaire.

\subsection{Sample Size Calculation}

The sample size was calculated using the formula by Naing et al. [17]. In Nigeria, institution-based incidence of infertility as reported from some parts shows that the South-Eastern Nigeria has a prevalent rate of $11.2 \%$ [9].

\subsection{Specimen Collection}

Blood samples were collected on day 2 - 3 of spontaneous menstrual cycle from both experimental subjects and control. About $5 \mathrm{ml}$ of the venous blood samples were withdrawn from the selected subjects and dispense into plain sample containers properly labeled with subject's name and age. The blood samples were left to coagulate spontaneously, centrifuged at $1000 \times \mathrm{g}$ for $15-20$ minutes and the serum separated immediately into plain sterile sample bottles with Pasteur pipette and the test carried out immediately. Samples not assayed immediately were stored frozen in the refrigerator at $2^{\circ} \mathrm{C}-8^{\circ} \mathrm{C}$ for 7 days.

\subsection{Biochemical Determinations}

Serum estradiol (E2) (Product Code: 4925-300), follicle stimulating hormone (FSH) (Product Code: 425-300), luteinizing hormone (LH) (Product Code: 525-300), prolactin (PRL) (Product code: 725-300) and anti-mullerian hormone (AMH) (Product code: 9725-300), were determined using Accu Bind enzymelinked immunosorbent assay (ELISA) microwells produced Monobind Inc., Lake Forest CA 92630, USA. The tests were read using microplate reader, Model: STAT FAX 303/PLUS, Serial number 303-6668 manufactured by Awareness Technology Inc., Palm City, FL 34990.

\subsection{Statistical Analysis}

The statistical software used for the analysis and graphics presentation is the Statistical Analysis System (SAS), STAT 15.1, developed by SAS Institute, North Carolina State University, USA. Data are presented as means \pm SEM. Comparison 
of means of groups that are more than two was done using analysis of variance (ANOVA), and the Tukey test of multiple comparison was used to test for variance within and across groups. Variation between two groups was done using the Student t-test analysis while Chi-square analysis was used to compare percentages. The Pearsons correlation was used to determine the correlations between parameters. Variation in means of parameters was considered statistically significant at $\mathrm{p}<0.05$.

\section{Results}

\subsection{Distribution of Age (Years) of Study Subjects}

The distribution of the age of the subjects in the study (Figure 1) shows that $15 \%$ of the studied population were found in the control group ( $<20$ years) while $35 \%$ of the subjects were in group 1 ( $20-29$ years) of age. Similarly, $25 \%$ of the subjects were in group 2 (30 - 39 years) while $25 \%$ of the subjects were in group 3 (30 - 49 years).

The means \pm SEM of serum AMH by experimental groups was $1602.44 \pm$ $54.42 \mathrm{pg} / \mathrm{ml}$ for control, $848.06 \pm 23.04 \mathrm{pg} / \mathrm{ml}$ for group $1,26.74 \pm 1.28 \mathrm{pg} / \mathrm{ml}$ for group 2, while group 3 was $10.37 \pm 1.26 \mathrm{pg} / \mathrm{ml}$ and significant difference in the means was observed between experimental groups and control $(\mathrm{p}<0.0001, \mathrm{~F}=$ 663.96). The mean of serum AMH for control subjects was significantly ( $\mathrm{p}<$ 0.05 ) different from the AMH means in groups 1 - 3. Similarly, the comparison of the mean of AMH between group 1 with the other groups showed significant difference $(\mathrm{p}<0.05)$. No significant $(\mathrm{p}>0.05)$ difference in mean of serum $\mathrm{AMH}$ was seen between 2 and 3 . The box plot analysis showing the trend of decrease of serum AMH concentrations as the age of the subjects increase from control to experimental groups $1-3$ is shown in Figure 2.

The mean \pm SEM of FSH in the control subjects was $4.90 \pm 0.22 \mathrm{mIU} / \mathrm{ml}$, $12.59 \pm 0.79 \mathrm{mIU} / \mathrm{ml}$ for group $1,30.59 \pm 1.31 \mathrm{mIU} / \mathrm{ml}$ for group 2 , and $41.59 \pm$ $1.59 \mathrm{miU} / \mathrm{ml}$ for group 3 . The means of FSH by control and experimental groups showed that they were significantly different $(\mathrm{p}<0.0001, \mathrm{~F}=229.65)$. The Tukey test of multiple comparison analysis of the means of FSH within the experimental groups and control shows that the mean of serum FSH is significantly $(\mathrm{p}<$ 0.05 ) different from each other. Also, the box plot analysis showing the trend of increase in the mean of FSH by the control and experimental groups is shown in Figure 3.

The boxplot analysis of the mean \pm SEM of serum LH in the subjects by experimental groups and control is shown in Figure 4. The figure shows the mean \pm SEM of control is $5.01 \pm 0.22 \mathrm{mIU} / \mathrm{ml}, 15.02 \pm 1.13 \mathrm{mIU} / \mathrm{ml}$ for group $1,42.71$ $\pm 1.82 \mathrm{mIU} / \mathrm{ml}$ for group 2 , and $58.22 \pm 2.62 \mathrm{mIU} / \mathrm{ml}$ for group 3 and significant difference $(\mathrm{p}<0.0001, \mathrm{~F}=208.97)$ was observed between them. Turkey test of multiple comparison analysis of means of LH within the experimental groups and control showed significant $(\mathrm{p}<0.05)$ difference between each of the groups. 


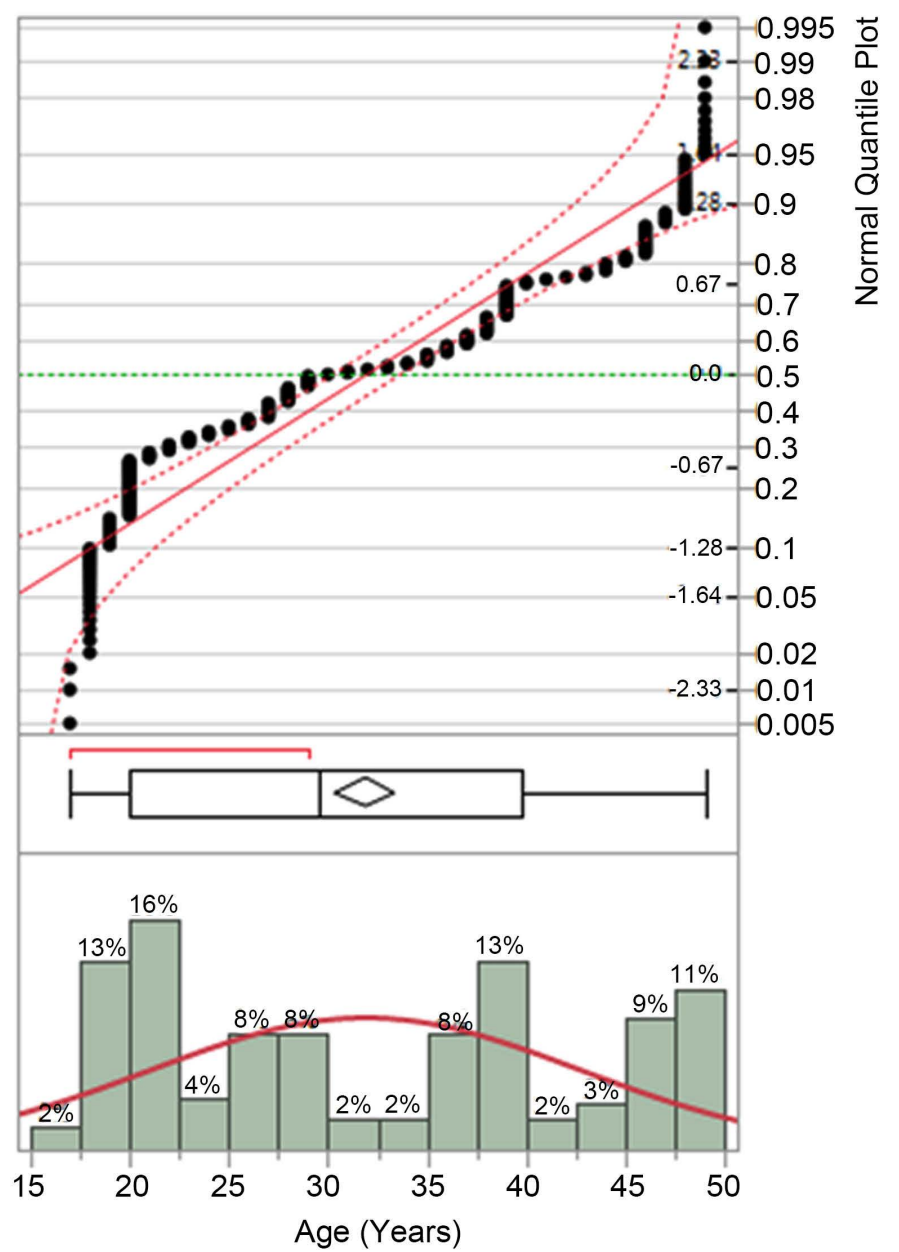

Figure 1. Distribution of age (years) of study subjects.

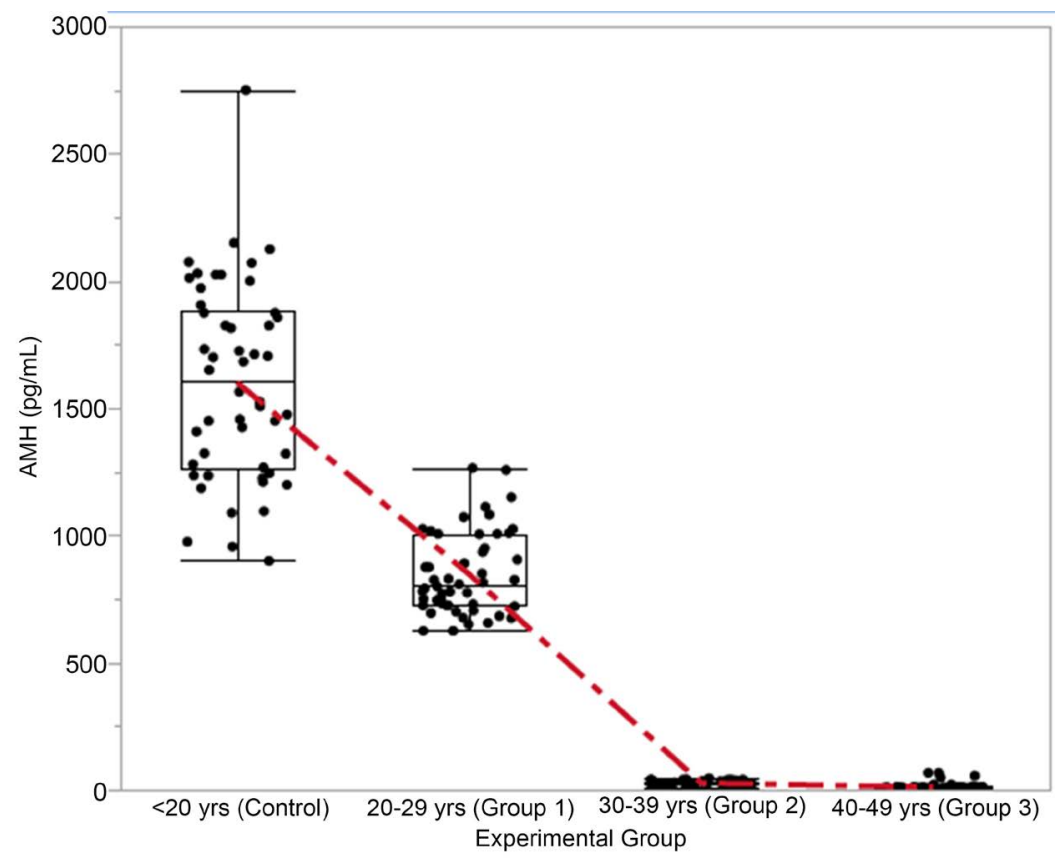

Figure 2. Boxplot of AMH by experimental groups. 


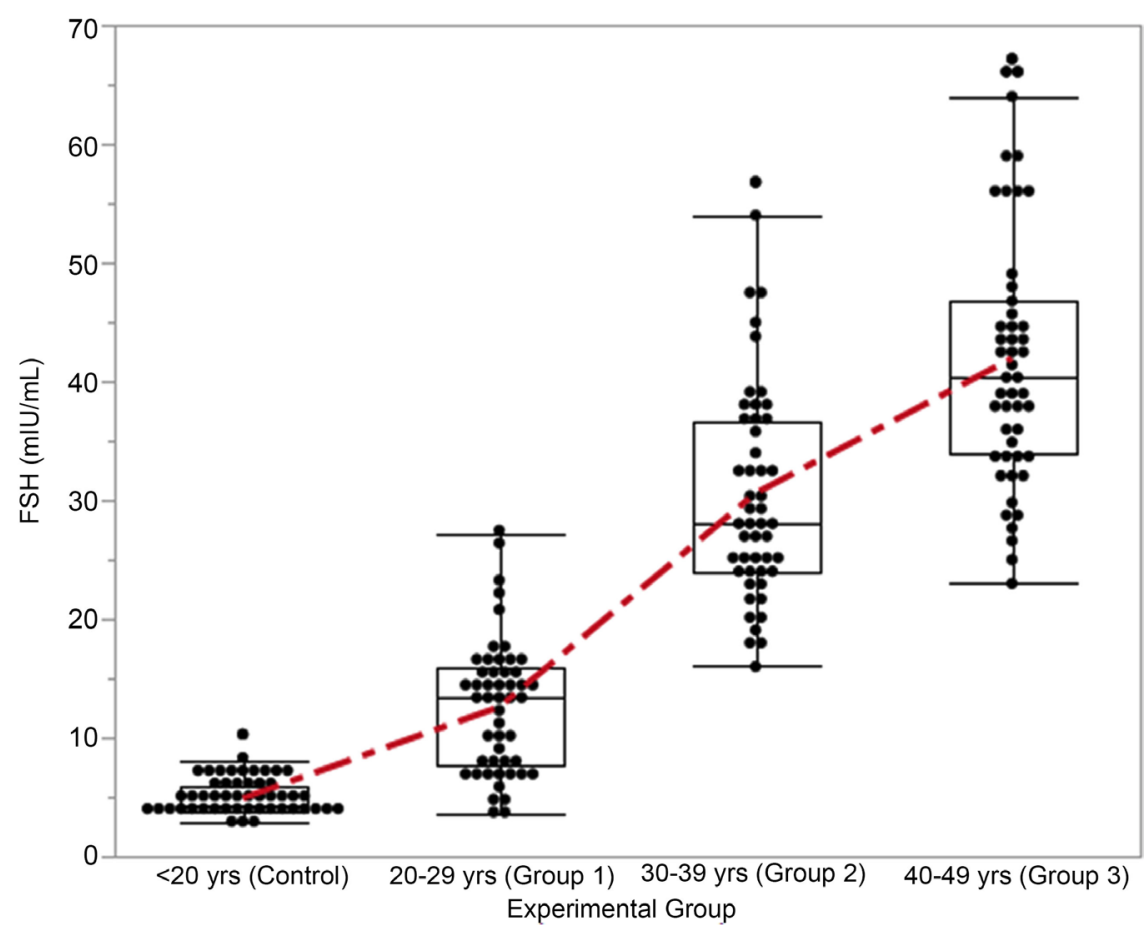

Figure 3. Box plot of FSH by experimental groups.

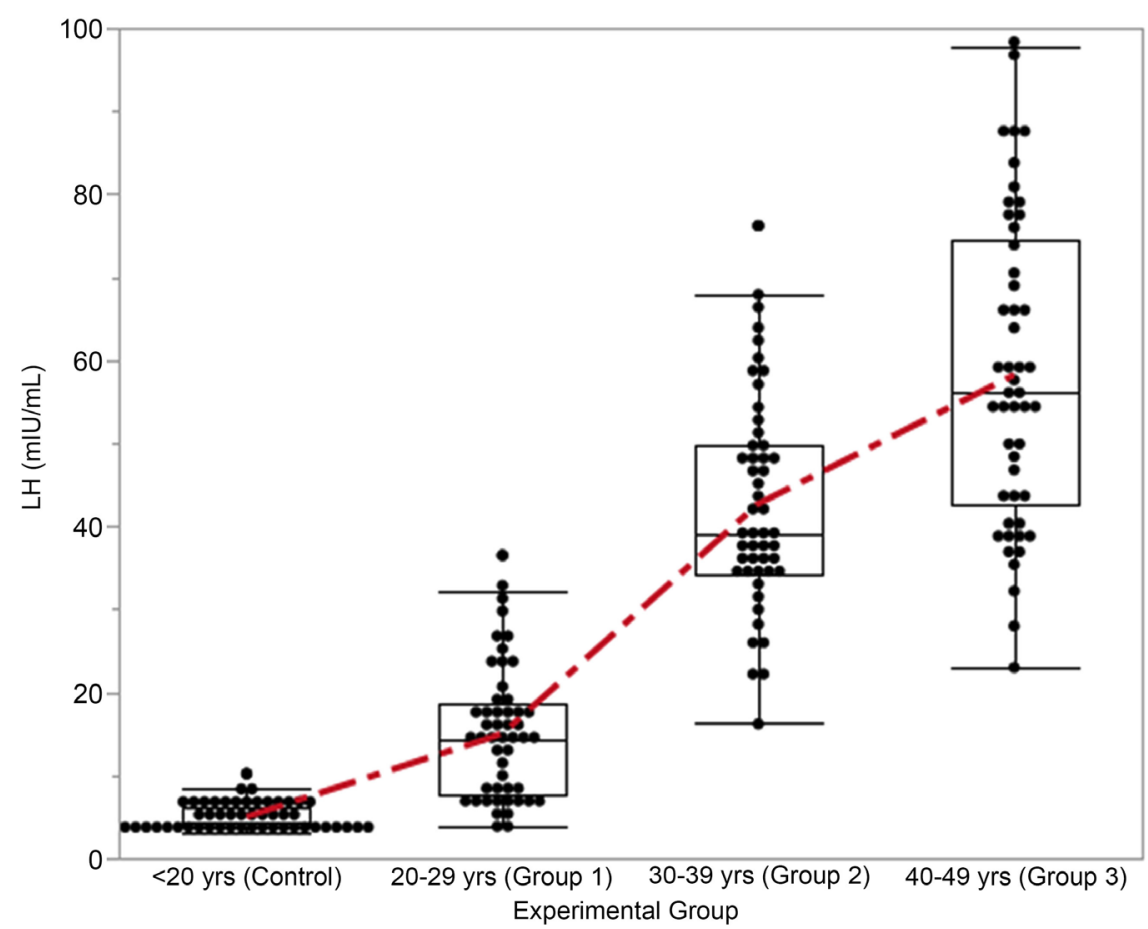

Figure 4. Boxplot of LH by experimental groups.

The mean \pm SEM of serum E2 by experimental groups and control (Figure 5) were $63.16 \pm 1.95 \mathrm{pg} / \mathrm{ml}$ for control, $94.10 \pm 5.56 \mathrm{pg} / \mathrm{ml}$ for group $1,58.84 \pm 4.01$ $\mathrm{pg} / \mathrm{ml}$ for group 2 , and $36.7 \pm 1.59 \mathrm{pg} / \mathrm{ml}$ for group 3 and significant difference $(\mathrm{p}<0.0001, \mathrm{~F}=41.92)$ was observed between them. The mean of serum E2 for 


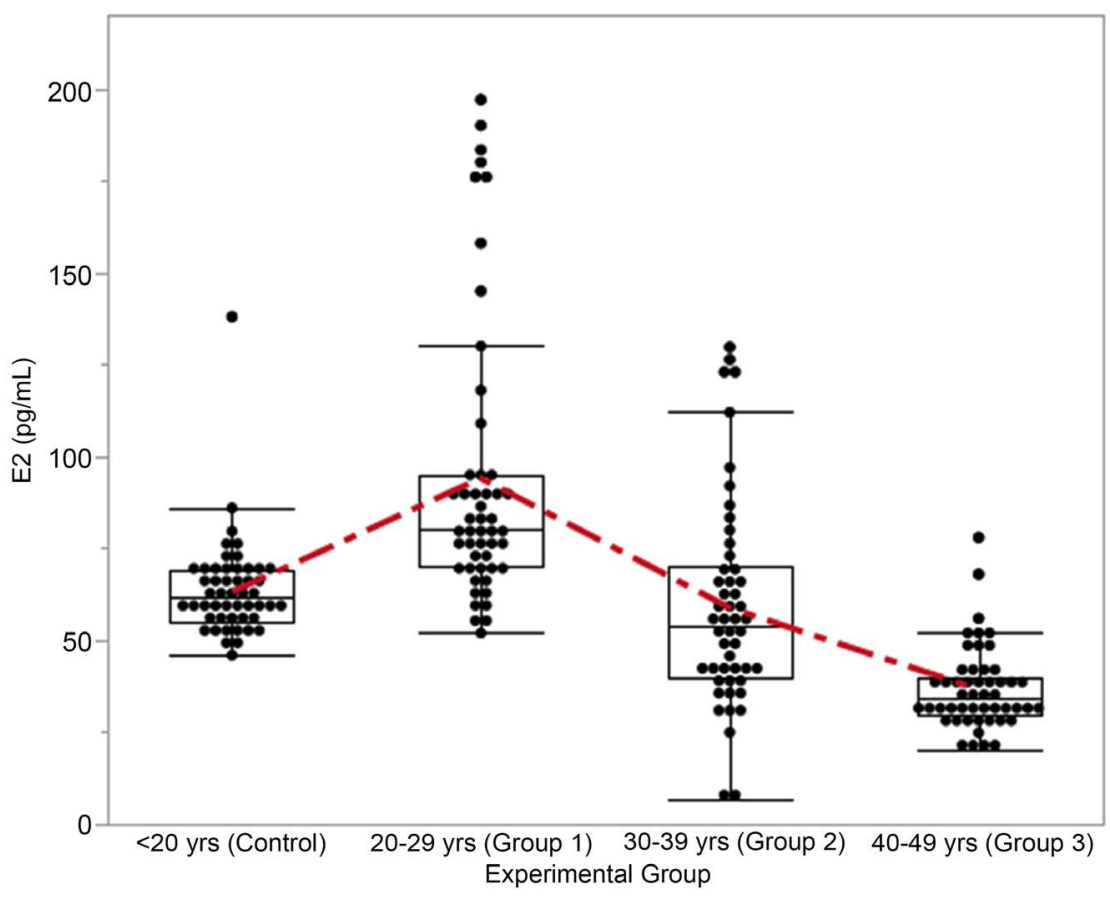

Figure 5. Boxplot of E2 by experimental groups.

the control subjects was significantly $(\mathrm{p}<0.05)$ different from the E2 means in group 1 and 3. Similarly, the comparison of mean of E2 for group 1 with the other groups showed significant difference $(\mathrm{p}<0.05)$. No significant difference $(\mathrm{p}>0.05)$ in mean of E2 was observed between the control and group 2.

The mean \pm SEM of prolactin by experimental groups and control was $8.26 \pm$ $0.39 \mathrm{ng} / \mathrm{ml}$ for the control, $11.65 \pm 0.67 \mathrm{ng} / \mathrm{ml}$ for group $1,11.99 \pm 1.49 \mathrm{ng} / \mathrm{ml}$ for group 2, and $2.90 \pm 0.29 \mathrm{ng} / \mathrm{ml}$ for group 3 . The means of serum prolactin by experimental groups and control showed significant difference $(\mathrm{p}<0.0001, \mathrm{~F}=$ 24.38). The comparison of the means of prolactin within the groups showed that while the means of serum prolactin for the control, group 1 and group 3 were significantly $(\mathrm{p}<0.05)$ different from each other, no significant difference $(\mathrm{p}>$ 0.05 ) was observed between the means of group 1 and group 2 . The box plot analysis indicating the trend of PRL for the control and experimental groups is shown in Figure 6.

The computation of the means of FSH/LH ratio for the control and experimental groups show that the mean \pm SEM of FSH/LH ratio for the control and experimental subjects in group 1 were $0.98 \pm 0.01$ and $0.89 \pm 0.02$ while the means for group 2 and group 3 were $0.74 \pm 0.03$ and $0.75 \pm 0.02$ respectively. The comparison of the means shows that they were significantly different $(\mathrm{p}<$ $0.0001, \mathrm{~F}=35.73$ ). Tukey test of multiple comparison analysis showed that the means of the control, group 1 and group 2 were significantly $(\mathrm{p}<0.05)$ different from each other while no significant difference $(p>0.05)$ was seen between the means of group 2 and group 3. The box plot analysis of FSH/LH ratio showing the trend of $\mathrm{FSH} / \mathrm{LH}$ ratio in the control and experimental groups is shown in Figure 7. 


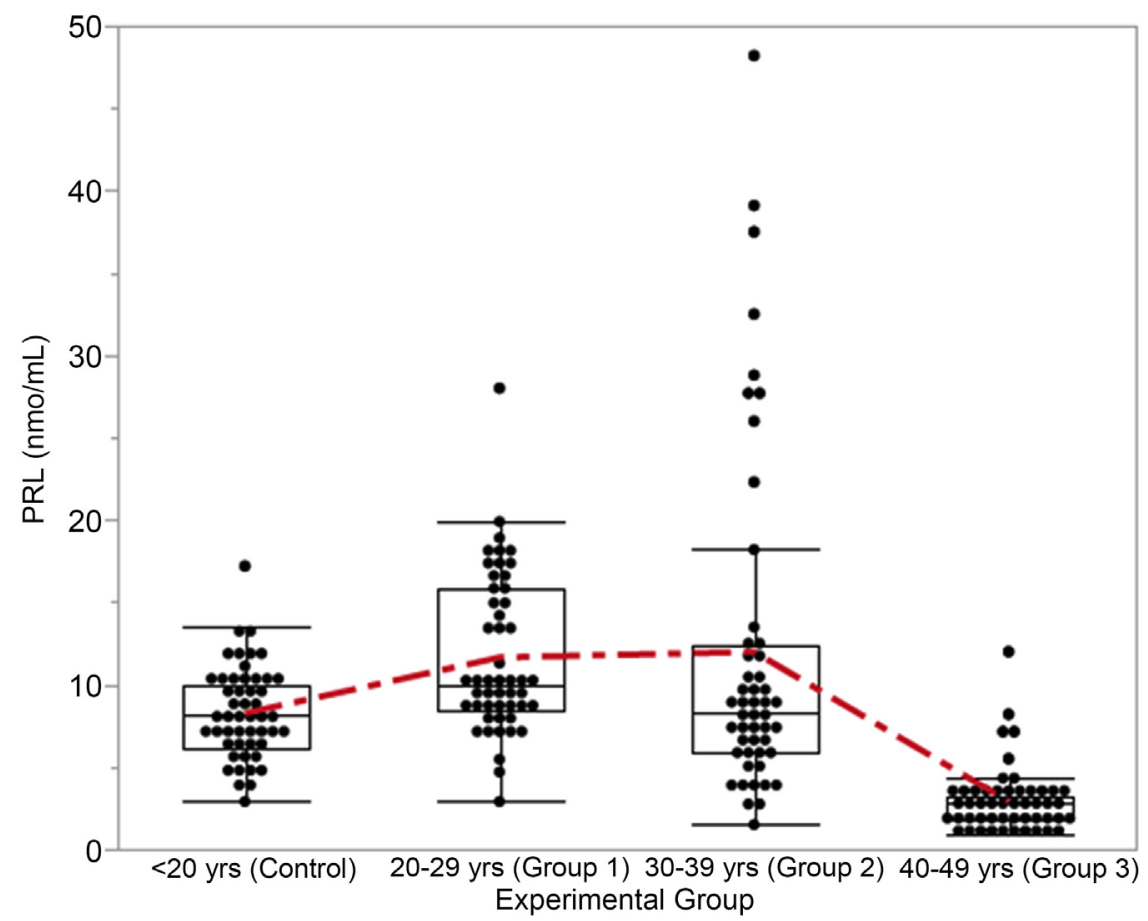

Figure 6. Boxplot of prolactin by experimental groups.

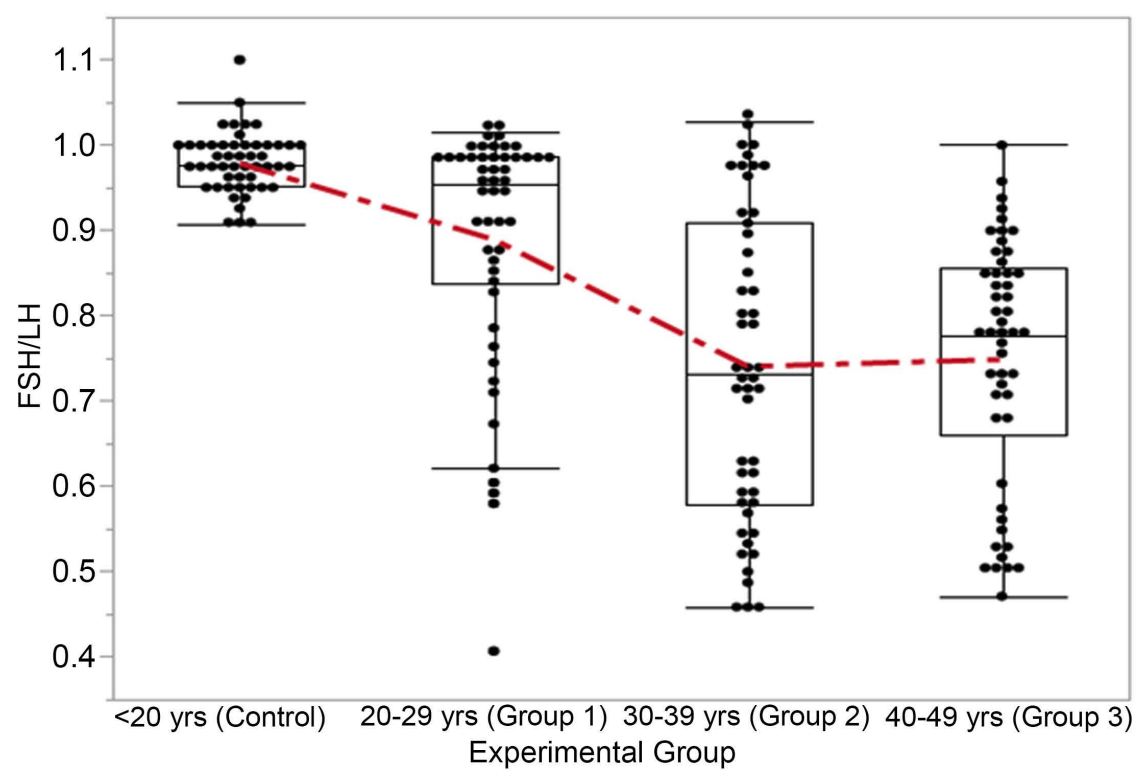

Figure 7. Boxplot of FSH: LH ratio by experimental groups.

\subsection{Pearson Correlations among Hormonal Parameters of Study Subjects}

Pearson correlation between hormonal parameters of $<20$ years old subjects (control group) is shown in Table 1. The table shows that negative correlations exist between FSH and AMH $(r=-0.4724, \mathrm{p}<0.0005)$, LH and AMH $(r=$ $-4832, \mathrm{p}<0.0004)$, E2 and AMH $(\mathrm{r}=-0.4227, \mathrm{p}<0.0022)$, PRL and AMH $(\mathrm{r}=$ $-0.4326, \mathrm{p}<0.0016)$. However, LH and FSH $(\mathrm{r}=0.9952, \mathrm{p}<0.0001)$, E2 and 
Table 1. Pearson correlation between hormonal parameters of control subjects $(<20$ years).

\begin{tabular}{cccccc}
\hline Parameter & by Parameter & Correlation & Lower 95\% & Upper 95\% & P-Value \\
\hline FSH $(\mathrm{mIU} / \mathrm{mL})$ & AMH $(\mathrm{pg} / \mathrm{mL})$ & -0.4724 & -0.6635 & -0.2234 & $0.0005^{* * *}$ \\
$\mathrm{LH}(\mathrm{mIU} / \mathrm{mL})$ & AMH $(\mathrm{pg} / \mathrm{mL})$ & -0.4832 & -0.6713 & -0.2367 & $0.0004^{* * *}$ \\
$\mathrm{LH}(\mathrm{mIU} / \mathrm{mL})$ & FSH $(\mathrm{mIU} / \mathrm{mL})$ & 0.9952 & 0.9915 & 0.9973 & $<0.0001^{* * * *}$ \\
$\mathrm{E} 2(\mathrm{pg} / \mathrm{mL})$ & AMH $(\mathrm{pg} / \mathrm{mL})$ & -0.4227 & -0.6273 & -0.1636 & $0.0022^{* *}$ \\
E2 $(\mathrm{pg} / \mathrm{mL})$ & FSH $(\mathrm{mIU} / \mathrm{mL})$ & 0.6487 & 0.4520 & 0.7853 & $<0.0001^{* * * *}$ \\
E2 $(\mathrm{pg} / \mathrm{mL})$ & $\mathrm{LH}(\mathrm{mIU} / \mathrm{mL})$ & 0.6361 & 0.4347 & 0.7769 & $<0.0001^{* * * *}$ \\
PRL $(\mathrm{ng} / \mathrm{mL})$ & AMH $(\mathrm{pg} / \mathrm{mL})$ & -0.4356 & -0.6367 & -0.1789 & $0.0016^{* *}$ \\
\hline
\end{tabular}

Significance Level: ${ }^{*}=\mathrm{p}<0.05,{ }^{* *}=\mathrm{p}<0.01,{ }^{* * *}=\mathrm{p}<0.001,{ }^{* * * *}=\mathrm{p}<0.0001$.

FSH $(r=0.6487, \mathrm{p}<0.0001)$, and E2 by LH $(\mathrm{r}=0.6361, \mathrm{p}<0.0001)$ were positively correlated.

Pearson correlations between hormonal parameters of 20 - 29 years old subjects (Group 1) is shown in Table 2. The table shows that FSH and AMH ( $\mathrm{r}=$ $-0.7388, \mathrm{p}<0.0001)$, LH and AMH $(\mathrm{r}=-0.7000, \mathrm{p}<0.0001)$, E2 and AMH $(\mathrm{r}=$ $-0.5604, \mathrm{p}<0.0001), \mathrm{PRL}$ and AMH $(\mathrm{r}=-0.3174, \mathrm{p}<0.0247)$, FSH/LH and FSH $(\mathrm{r}=-0.2844, \mathrm{p}<0.0 .0453)$, and FSH/LH ratio and LH $(\mathrm{r}=-0.6782, \mathrm{p}<0.0001)$ were negatively correlated $(\mathrm{p}<0.0001)$. Strong positive correlations were seen between LH and FSH $(r=0.8849, \mathrm{p}<0.0001)$, E2 and FSH $(\mathrm{r}=0.6793, \mathrm{p}<$ $0.0001)$, E2 and LH $(r=0.5937, \mathrm{p}<0.0001)$, PRL and FSH $(\mathrm{r}=0.3677, \mathrm{p}<$ $0.0086)$ and PRL and LH $(0.4172, \mathrm{p}<0.0026)$ as shown in Table 2.

\subsection{Pearson Correlations between Hormonal Profile Parameters of 30 - 39 Years Old Subjects}

Table 3 shows Pearson correlations between hormonal parameters of 30 - 39 years old subjects (group 2). FSH and AMH ( $\mathrm{r}=-0.5593, \mathrm{p}<0.0001), \mathrm{LH}$ and AMH $(r=-0.4135, p<0.0028)$, E2 and FSH $(r=-0.4915, p<0.0003)$, and E2 and LH ( $\mathrm{r}=-0.3325, \mathrm{p}<0.0183)$ showed negative correlations while LH and FSH $(r=0.6754, \mathrm{p}<0.0001)$ and FSH/LH by FSH $(\mathrm{r}=0.3140, \mathrm{p}<0.0264)$ showed positive correlation.

\subsection{Pearson Correlations between Hormonal Profile Arameters of 40 - 49 Years Old Subjects}

Table 4 shows Pearson correlations between hormonal parameters of $40-49$ years old subjects (Group 3). FSH and AMH ( $\mathrm{A}=-0.02882, \mathrm{p}<0.0424)$, LH and AMH ( $\mathrm{r}=-0.3267, \mathrm{p}<0.0206)$, E2 and FSH $(\mathrm{r}=-0.5705, \mathrm{p}<0.0001)$, E2 by LH $(r=-0.6091, p<0.0001)$, PRL and FSH $(r=-0.3225, p<0.0224)$, PRL and LH $(r=-0.3854, p<0.0057)$ and FSH/LH and LH $(r=-0.6252, p<0.0001)$ showed negative $(\mathrm{p}<0.05)$ correlations while LH and FSH $(\mathrm{r}=0.7354, \mathrm{p}<$ $0.0001)$, and E2 and AMH $(r=0.7184, p<0.0001)$ showed positive $(\mathrm{p}<0.05)$ correlations. 
Table 2. Pearson correlations between hormonal parameters of 20 - 29 years old subjects.

\begin{tabular}{cccccc}
\hline Variable & by Variable & Correlation & Lower 95\% & Upper 95\% & P-Value \\
\hline FSH $(\mathrm{mIU} / \mathrm{mL})$ & AMH $(\mathrm{pg} / \mathrm{mL})$ & -0.7388 & -0.8437 & -0.5797 & $<0.0001^{* * * *}$ \\
LH $(\mathrm{mIU} / \mathrm{mL})$ & AMH $(\mathrm{pg} / \mathrm{mL})$ & -0.7000 & -0.8188 & -0.5236 & $<0.0001^{* * * *}$ \\
LH $(\mathrm{mIU} / \mathrm{mL})$ & FSH $(\mathrm{mIU} / \mathrm{mL})$ & 0.8849 & 0.8049 & 0.9334 & $<0.0001^{* * * *}$ \\
E2 $(\mathrm{pg} / \mathrm{mL})$ & AMH $(\mathrm{pg} / \mathrm{mL})$ & -0.5604 & -0.7256 & -0.3342 & $<0.0001^{* * * *}$ \\
E2 $(\mathrm{pg} / \mathrm{mL})$ & FSH $(\mathrm{mIU} / \mathrm{mL})$ & 0.6793 & 0.4945 & 0.8054 & $<0.0001^{* * * *}$ \\
E2 $(\mathrm{pg} / \mathrm{mL})$ & LH $(\mathrm{mIU} / \mathrm{mL})$ & 0.5937 & 0.3778 & 0.7484 & $<0.0001^{* * * *}$ \\
PRL $(\mathrm{ng} / \mathrm{mL})$ & AMH $(\mathrm{pg} / \mathrm{mL})$ & -0.3174 & -0.5474 & -0.0429 & $0.0247^{*}$ \\
PRL $(\mathrm{ng} / \mathrm{mL})$ & FSH $(\mathrm{mIU} / \mathrm{mL})$ & 0.3677 & 0.0995 & 0.5861 & $0.0086^{* *}$ \\
PRL $(\mathrm{ng} / \mathrm{mL})$ & LH $(\mathrm{mIU} / \mathrm{mL})$ & 0.4172 & 0.1571 & 0.6232 & $0.0026^{* *}$ \\
FSH/LH & AMH $(\mathrm{pg} / \mathrm{mL})$ & 0.3863 & 0.1210 & 0.6001 & $0.0056^{* *}$ \\
FSH/LH & FSH $(\mathrm{mIU} / \mathrm{mL})$ & -0.2844 & -0.5215 & -0.0066 & $0.0453^{*}$ \\
FSH/LH & LH $(\mathrm{mIU} / \mathrm{mL})$ & -0.6782 & -0.8047 & -0.4930 & $<0.0001^{* * * *}$ \\
\hline
\end{tabular}

Experimental Group: Group $1\left[20-29\right.$ years, $($ Mean $=25.46 \pm 0.41)$ ]. Significance Level: ${ }^{*}=\mathrm{p}<0.05,{ }^{* *}=\mathrm{p}$ $<0.01,{ }^{* * *}=\mathrm{p}<0.001,{ }^{* * * *}=\mathrm{p}<0.0001$.

Table 3. Pearson correlations between hormonal profile parameters of 30 - 39 years old.

\begin{tabular}{cccccc}
\hline Parameter & by Parameter & Correlation & Lower 95\% & Upper 95\% & P-Value \\
\hline FSH $(\mathrm{mIU} / \mathrm{mL})$ & AMH $(\mathrm{pg} / \mathrm{mL})$ & -0.5593 & -0.7248 & -0.3328 & $<0.0001^{* * * *}$ \\
LH $(\mathrm{mIU} / \mathrm{mL})$ & AMH $(\mathrm{pg} / \mathrm{mL})$ & -0.4135 & -0.6204 & -0.1527 & $0.0028^{* *}$ \\
$\mathrm{LH}(\mathrm{mIU} / \mathrm{mL})$ & FSH $(\mathrm{mIU} / \mathrm{mL})$ & 0.6754 & 0.4890 & 0.8028 & $<0.0001^{\star}$ \\
E2 $(\mathrm{pg} / \mathrm{mL})$ & FSH $(\mathrm{mIU} / \mathrm{mL})$ & -0.4915 & -0.6772 & -0.2469 & $0.0003^{* *}$ \\
E2 $(\mathrm{pg} / \mathrm{mL})$ & LH $(\mathrm{mIU} / \mathrm{mL})$ & -0.3325 & -0.5591 & -0.0597 & $0.0183^{*}$ \\
FSH/LH & FSH $(\mathrm{mIU} / \mathrm{mL})$ & 0.3140 & 0.0390 & 0.5447 & $0.0264^{*}$ \\
FSH $/ \mathrm{LH}$ & LH $(\mathrm{mIU} / \mathrm{mL})$ & -0.4609 & -0.6552 & -0.2094 & $0.0008^{* * *}$ \\
\hline
\end{tabular}

Experimental Group: Group $2[30$ - 39 years, $($ Mean $=36.78 \pm 0.35)]$. Significance Level: ${ }^{\star}=p<0.05,{ }^{* *}=p$ $<0.01,{ }^{* * *}=\mathrm{p}<0.001,{ }^{* * * *}=\mathrm{p}<0.0001$.

Table 4. Pearson correlations between hormonal profile of 40 - 49 years old subjects.

\begin{tabular}{cccccc}
\hline Parameter & by Parameter & Correlation & Lower 95\% & Upper 95\% & P-Value \\
\hline FSH $(\mathrm{mIU} / \mathrm{mL})$ & AMH $(\mathrm{pg} / \mathrm{mL})$ & -0.2882 & -0.5244 & -0.0107 & $0.0424^{*}$ \\
LH $(\mathrm{mIU} / \mathrm{mL})$ & AMH $(\mathrm{pg} / \mathrm{mL})$ & -0.3267 & -0.5546 & -0.0532 & $0.0206^{*}$ \\
LH $(\mathrm{mIU} / \mathrm{mL})$ & FSH $(\mathrm{mIU} / \mathrm{mL})$ & 0.7354 & 0.5746 & 0.8415 & $<0.0001^{* * * *}$ \\
E2 $(\mathrm{pg} / \mathrm{mL})$ & AMH $(\mathrm{pg} / \mathrm{mL})$ & 0.7184 & 0.5500 & 0.8306 & $<0.0001^{* * * *}$ \\
E2 $(\mathrm{pg} / \mathrm{mL})$ & FSH $(\mathrm{mIU} / \mathrm{mL})$ & -0.5705 & -0.7325 & -0.3473 & $<0.0001^{* * * *}$ \\
E2 $(\mathrm{pg} / \mathrm{mL})$ & LH $(\mathrm{mIU} / \mathrm{mL})$ & -0.6091 & -0.7588 & -0.3983 & $<0.0001^{* * * *}$ \\
PRL $(\mathrm{ng} / \mathrm{mL})$ & FSH $(\mathrm{mIU} / \mathrm{mL})$ & -0.3225 & -0.5514 & -0.0485 & $0.0224^{*}$ \\
PRL $(\mathrm{ng} / \mathrm{mL})$ & LH $(\mathrm{mIU} / \mathrm{mL})$ & -0.3854 & -0.5994 & -0.1199 & $0.0057^{* *}$ \\
FSH/LH & LH $(\mathrm{mIU} / \mathrm{mL})$ & -0.6252 & -0.7696 & -0.4199 & $<0.0001^{* * * *}$ \\
\hline
\end{tabular}




\section{Discussion}

Reproductive aging is accompanied with diminution of primordial follicle pool and gradual decline in the quality of oocyte. As observed in the present study, serum AMH decreases significantly as the age of individuals increases. Since infertility is synonymous with advanced age, its evaluation is of great importance in ART. This is in consonance with the reports of Broer et al. [18] that serum $\mathrm{AMH}$ is the best possible marker for screening and is also helpful for quick referral of women who are facing challenges of child birth to IVF centres for intervention.

Using the standard reference limit of $(3.0$ - 12) $\mathrm{mIU} / \mathrm{mL}$ for FSH, $(0.5$ - 10.5) $\mathrm{mIU} / \mathrm{mL}$ for serum LH level, $44-196 \mathrm{pg} / \mathrm{mL}$ for E2 and $1.2-19.5 \mathrm{ng} / \mathrm{mL}$ for PRL, it was observed from the study that the control group (age $<20$ years) had serum FSH, LH and E2 levels within the standard reference limit. Participants in this group do not require ovarian stimulation to enable pregnancy; they also stand a better chance of achieving pregnancy naturally, bearing in mind the role of E2 in development of follicles and choosing of dominant follicles. Smotrich et al. [19] had earlier stated that subjects with E2 within $65-75 \mathrm{pg} / \mathrm{mL}$ achieved a higher pregnancy rate when cycle is initiated. Patients in this category are classified by Rehman et al. [20], as high responders. This finding is similar to the report of Al-Fahham \& Al-Norway [21], when they carried out a study on the role of FSH, LH and prolactin hormones on female infertility. They observed normal FSH and LH levels among women within the age of $17-20$ years. Observation from this study is also supported by the finding of Sudha \& Ruddy [22] as reported in their cross-sectional study on the causes of infertility in women. Huang et al. [23] reported that patients with normal serum prolactin levels had higher fertilization and cleavage occurrences and could achieve pregnancy without taking hyperprolactinaemic drugs.

The serum FSH, LH, E2 and PRL levels of study participants within 20 - 29 years of age showed a slight increase in serum levels above the standard reference limits. Subjects within this age bracket possessed the potential of achieving pregnancy naturally, and may or may not require ovulation induction or ovarian stimulation before they could be pregnant. This finding is in line with the study of Al-Fahham \& Al-Norway [21] and Sudha \& Ruddy [22]. However, with respect to E2, subjects with such raised E2 levels higher than $80 \mathrm{pg} / \mathrm{mL}$ would find it difficult to conceive naturally and when stimulated will exhibit poor response. This observation correlates with study carried out by Mutlu \& Erdem, [24] on basal E2 levels. They opined that subjects with basal estradiol levels of $80 \mathrm{pg} / \mathrm{mL}$ and above throughout their cycle prior to IVF treatment gets diminished occurrence of pregnancy for each cycle commenced and had increased withdrawal rate, when matched with patients whose estradiol levels measured below 80 $\mathrm{pg} / \mathrm{mL}$. Subjects in this age range with raised prolactin cannot conceive naturally unless the serum prolactin level is reduced with the help of hyperprolactinaemic drugs. 
The basal serum FSH and LH levels of subjects between age 30 - 39 years and 40 - 49 years were hgher than basal serum FSH and LH levels beyond the standard reference limit of $(3.0-12) \mathrm{mIU} / \mathrm{mL}$ and $(0.5-10.5) \mathrm{mIU} / \mathrm{mL}$ respectively, which shows an increasing trend as the age of participants in the study increases. This trend is traceable to poor ovarian reserve and interruption in the functions of the ovaries. This also implies that maturation of eggs and ovulation may not be possible in an advanced age. This is in agreement with the study of Sowers et al. [25], and Fang et al. [26] that significant increase in FSH levels with increasing age is a result of disturbances in the ovarian function which relates directly with infertility. The implication of elevated $\mathrm{LH}$ values points to cycle inconsistency, which hinders folliculogenesis and normal function of the ovaries, an important role played by $\mathrm{LH}$, and this will nonetheless, lead to infertility and increased occurrence of miscarriages [27] [28]. However, serum E2 levels of group 2 (30 - 39 years), and group 3 (40 - 49 years), was observed to be low, though within the standard reference limit, but lower than $65 \mathrm{pg} / \mathrm{mL}$. Women in this category will find it extremely difficult to achieve pregnancy naturally. They are classified also as poor responders when subjected to ovarian stimulation and induction. This finding corresponds with the scientific opinion of Smotrich et al. [19] that women with low serum E2 values will respond poorly during ovarian stimulation or induction during IVF intervention. The PRL level of group 3 was observed to be lower than normal when compared with the control. This variation could be as a result of the transient nature of prolactin and its secretion from different parts of the body. These, however, ruled out serum PRL as ideal biomarker in evaluating ovarian reserve. Nonetheless, patients with normal prolactin levels have an advantage during in vitro fertilization when compared with patients with high prolactin levels, which agree with the studies of Reinthaller et al. [29] and Ekwempu et al. [30].

The present study also considered baseline FSH: LH ratio of both experimental subjects and controls, using FSH/LH cut-off value of $\leq 0.90$ and $\geq 2$ [31]. Observation from our study showed that the control group $<20$ years will respond better should there be IVF intervention in a situation where conception could not be achieved naturally while groups 1 (20 - 29 years), group 2 (30 - 39 years) and group 3 (40 - 49 years) of age will experience difficulty in getting pregnant naturally, and may not benefit optimally during IVF intervention. The implication of the above is that participants in the control group stand a better chance to benefit from in vitro fertilization and embryo transfer than participants in groups 1, 2 and 3. This observation is at par with the report of Liu et al. [31] that FSH: LH ratio of $\leq 0.90$ and $\geq 2$ is associated with higher rate of cancellation of IVF and embryo transfer.

In this study, correlation analysis of serum AMH with FSH and age showed that serum AMH and serum FSH weighted by age had a strong significant inverse relationship $(\mathrm{r}=-0.7800, \mathrm{p}<0.0001)$. This negative correlation between serum AMH and serum FSH was observed across the four (4) experimental groups. The AMH levels decreased significantly $(\mathrm{p}<0.0001)$ across the 3 expe- 
rimental groups as the age of participants increases. The serum FSH levels showed a significant increase $(\mathrm{p}<0.0001)$ in groups 1,2 and 3 , when compared with the control group as the age of the participants increases. This implies that baseline serum FSH increases in infertility with a corresponding decrease in serum $\mathrm{AMH}$ as shown in the present study. The present observation is in agreement with the finding of Barbakadze et al. [32] that with age, serum AMH and basal AFC levels decreases very strongly, while serum FSH levels increased moderately.

The present study also correlated serum AMH and LH and observed a significantly strong negative $(\mathrm{r}=-0.7663, \mathrm{p}<0.0001)$ correlation, weighted by age, between serum AMH and LH levels. The same inverse relationship was observed across the four (3) experimental groups. This finding correlates with the report by Bala et al. [33] when they investigated the correlation of AMH, FSH and LH in female infertility and observed that serum AMH, FSH and LH are negatively associated. Decreased serum AMH levels with increased age were synonymous with increased serum FSH and LH levels. Similar findings were reported by de Vet et al. [34] where they proposed that differences in serum AMH levels have been shown to take place much earlier in the series of happenings that is related to ovarian aging while Burger et al. [35] stated that increased serum FSH values are not seen until cycles become irregular.

The correlation analysis performed between serum E2 and serum AMH, weighted by age, showed a significant weak positive correlation $(\mathrm{r}=0.3150, \mathrm{p}<$ 0.0001). The correlation between serum E2 and FSH showed an inverse correlation $(\mathrm{r}=-0.5011, \mathrm{p}<0.0001)$. The same inverse correlation $(\mathrm{r}=-0.4908, \mathrm{p}<$ 0.0001 ) was observed between E2 and LH. The observed inconsistency and fluctuation in correlation between serum estradiol and other biochemical markers is probably as a result of the multiple sites of E2 secretion. This factor, therefore, ruled out E2 as an ideal marker of ovarian pool. This observation agrees with the position of Jamil et al. [36] where they reported that serum E2 cannot be used singly as a marker of ovarian reserve because of the different sites of secretion of estradiol. This observation is in line with reports of meta-analysis by Broekmans et al. [37]. They concluded that basal E2 does not possess forecasting value like the other ovarian reserve test. This is the main reason why E2 cannot be classified nor recommended in clinical practice in the evaluation of ovarian reserve. While Mutlu \& Erdem [24], opined that addition of day 3 estradiol while estimating FSH levels could be helpful in reducing the occurrence of false negative results encountered when serum FSH is used alone and could assist clinicians in the explanation of FSH results.

An inverse correlation $(\mathrm{r}=-0.4356, \mathrm{p}<0.001)$ was observed between PRL and $\mathrm{AMH}$, weighted by age in the experimental subjects. This implies that increased serum prolactin levels (Hyperprolactinaemia) could lead to decrease in serum AMH levels which will in turn affect conception. This is similar to the reports of Ekwempu et al. [30] that hyperprolactinaemia is implicated in most 
cases of infertility. No significant difference ( $p>0.05$ ) was observed between serum PRL and FSH levels, serum PRL with LH levels, and between serum PRL and E2 levels, both in the experimental subjects weighted by age, and control. This implies that serum PRL does not have correlation with FSH, LH, and E2 based on our observation in the present study. This lack of correlation between serum PRL and other hormonal parameters could be attributed to the transient nature of serum prolactin. Its elevation above normal levels (hperprolactinaemia) could be as a result of other factors or medical conditions. This is in agreement with the report of Majumdar \& Margal [38] where they reported that hyperplactinaemia can be physiological, pathological or idiopathic. This shows that serum PRL levels cannot be seen as a useful biochemical indicator in ovarian reserve assessments, but could be used for fertility evaluation to rule out hyperproteinaemia which could affect the chances of pregnancy. Serum prolactin has an important role to play in the regulation of reproductive functions.

The correlation between FSH/LH ratio and other hormonal parameters used in the present study in the control participants showed no correlation between FSH/LH ratio and AMH. In group 1 (20 - 29 years) a moderate positive correlation $(\mathrm{r}=0.3863, \mathrm{p}<0.0056)$ between $\mathrm{FSH} / \mathrm{LH}$ ratio and AMH was observed. In group 2 and group 3, we observed that no correlation existed between FSH/LH ratio and $\mathrm{AMH}$. This implies that $\mathrm{FSH} / \mathrm{LH}$ ratio with $\mathrm{AMH}$ cannot be a good ovarian reserve predictor when combined. Nonetheless, FSH/LH ratio can be used independently in forecasting pregnancy outcome and response in controlled ovarian stimulation. This is in agreement with the report of Mukherjee et al. [39]; Kofinas \& Elias [40] on the clinical use of FSH/LH ratio as an independent predictor of response to controlled ovarian stimulation during IVF treatment.

\section{Conclusion}

The evaluation of levels of anti-Mullerian hormone, follicle stimulating hormone, luteinizing hormone, estradiol, prolactin and FSH/LH ratio across the age range of the population studied shows that women within the control and experimental group 1 ( $<20$ years and $20-29$ years) consisting of $50 \%$ of the women studied have a better chance of achieving pregnancy naturally and may not therefore require ovarian stimulation to enable pregnancy.

\section{Author Contributions}

All authors were involved in the conception and design of the experiments. CEJO performed the experiments. EASB, CEJO analyzed the data, EASB, CEJO wrote the manuscript and EASB, CEJO, FUI, EON proof read the manuscript.

\section{Conflicts of Interest}

The authors declare no conflicts of interest regarding the publication of this paper. 


\section{References}

[1] (2010) National Guideline Clearinghouse Fertility: Assessment and Treatment for People with Fertility Problems.

http://www.rcog.org.uk/womens-health/clinical-guidance/fertility-assessment-and-t reatment-people-fertility-problems

[2] Menuba, I.E., Ugwu, E.O., Obi, S.N., Lawani, L.O. and Onwuka, C.I. (2014) Clinical Management and Therapeutic Outcome of Infertile Couples in Southeast Nigeria. Therapeutics and Clinical Risk Management, 10, 763-768. https://doi.org/10.2147/TCRM.S68726

[3] Okonofua, F.E. and Obi, H. (2009) Specialized versus Conventional Treatment of Infertility in Africa, Time for a Pragmatic Approach. African Journal of Reproductive Health, 13, 9-15.

[4] Ombelet, W., Cooke, I., Dyer, S., Serour, G. and Devroey, P. (2008) Infertility and the Provision of Infertility Medical Services in Developing Countries. Human Reproduction Update, 14, 605-621. https://doi.org/10.1093/humupd/dmn042

[5] Okohue, J.E., Onuh, S.O. and Ikimalo, J.I. (2013) Comparison of IVF/ICSI Outcome in Patients with Polcystic Ovarian Syndrome or Tubal Factor Infertility. Nigerian Journal of Clinical Practice, 16, 207-210. https://doi.org/10.4103/1119-3077.110164

[6] Omoaregba, J.O., James, B.O., Lawani, A.O., Morakinya, O. and Olotu, O.S. (2011) Psychosocial Characteristics of Female Infertility in a Tertiary Health Institution in Nigeria. Annals of African Medicine, 10, 19-24. https://doi.org/10.4103/1596-3519.76567

[7] Alvarez Nieto, C. (2006) Infertility: The Magnitude of This Problem. Revista de Enfermeria, 29, 56-62.

[8] Garcia, J.E. and Nelson, L.H. (2019) Infertility. http://www.emedicine.com/med

[9] Umeora, O.U., Ejikeme, B.N., Sunday-Adeoye, I. and Umeora, M.C. (2008) Sociocultural Impediments to Male Factor Infertility Evaluation in Rural Southeast Nigeria. Journal of Obstetrics and Gynaecology, 28, 23-36. https://doi.org/10.1080/01443610802044908

[10] van Balen, F. and Bos, H.M. (2009) The Social and Cultural Consequences of Being Childless in Poor-Resource Countries. Facts, Views \& Vision in ObGyn, 1, 106-121.

[11] Dyer, S.J., Abraham, N., Mokoena, N.E., Lamard, C.J. and van der Spury, Z.M. (2005) Psychological Distress among Women Suffering from Couple Infertility in South Africa: A Quantitative Assessment. Human Reproduction, 20, 1938-1943. https://doi.org/10.1093/humrep/deh845

[12] Cong, J., Li, P., Zheng, L. and Tan, J. (2016) Prevalence and Risk Factors of Infertility at a Rural Site of Northern China. PLOS ONE, 11, e0155563. https://doi.org/10.1371/journal.pone.0155563

[13] Unuane, D., Tournaye, H., Velkeniers, B. and Poppe, K. (2011) Endocrine Disorders and Female Infertility. Best Practice \& Research Clinical Endocrinology \& Metabolism, 25, 861-873. https://doi.org/10.1016/j.beem.2011.08.001

[14] te Velde, E.R. and Pearson, P.L. (2001) The Variability of Female Reproductive Ageing. Human Reproduction Update, 8, 141-154. https://doi.org/10.1093/humupd/8.2.141

[15] Menken, J., Trusell, J. and Larsen, U. (1986) Age and Infertility. Science, 233, 1389-1394. https://doi.org/10.1126/science.3755843

[16] O’Conner, K.A., Holman, D.J. and Wood, J.W. (1998) Declining Fecundity and Ovarian Ageing in Natural Fertility Populations. Maturitas, 30, 127-136. 
https://doi.org/10.1016/S0378-5122(98)00068-1

[17] Naing, L., Winn, T. and Rusli, B.N. (2006) Practical Issues in Calculating the Sample Size for Prevalence Studies. Archives of Orofacial Sciences, 1, 9-14.

[18] Broer, S.L., Eijkemans, M.J.C., Scheffer, G.J., van Rooij, I.A.J., de Vet, A. and Themmen, A.P.N. (2011) Anti Mullerian Hormone Predicts Menopause: A Long-Term Follow-Up Study in Normovulatory Women. The Journal of Clinical Endocrinology \& Metabolism, 96, 2532-2539. https://doi.org/10.1210/jc.2010-2776

[19] Smotrich, D.B., Widra, E.A. and Gindoff, P.R. (1995) Prognostic Value of Day 3 Estradiol on in Vitro Fertilization Outcome. Fertility and Sterility, 64, 1136-1140. https://doi.org/10.1016/S0015-0282(16)57974-6

[20] Rehman, R., Jawaid, S., Gul, H. and Khan, R. (2014) Impact of Peak Estradiol Levels on Reproductive Outcome of Intracytoplasmic Sperm Injection. Pakistan Journal of Medical Sciences, 30, 986-991. https://doi.org/10.12669/pjms.305.5175

[21] Al-Fahham, A.A. and Al-Nowainy, H.Q. (2016) The Role of FSH, LH, and Prolactin Hormones in Female Infertility. International Journal of PharmTech Research, 6, 110-118.

[22] Sudha, G. and Reddy, K.S.N. (2013) Causes of Female Infertility: A Cross Sectional Study. International Journal of Latest Research in Science and Technology, 2, 119-123.

[23] Huang, K.E., Bonfiglio, T.A. and Muechler, E.K. (1991) Transient Hyperprolactinaemia in Infertile Women with Luteal Phase Deficiency. Obstetrics \& Gynecology, 78, 651-655.

[24] Mutlu, M.F. and Erdem, A. (2012) Evaluation of Ovarian Reserve in Infertile Women. Journal of the Turkish-German Gynecological Association, 13, 196-103. https://doi.org/10.5152/jtgga.2012.28

[25] Sowers, M.R., Eyvazzadeh, A.D. and McConnell, D. (2008) Antimullerian Hormone and Inhibin B in the Definition of Ovarian Aging and the Menopause Transition. The Journal of Clinical Endocrinology \& Metabolism, 93, 3478-3483. https://doi.org/10.1210/jc.2008-0567

[26] Fang, T., Zheng, S., Wang, L., Yuan, P., Li, P., Ouyang, N., Zheng, L. and Wang, W. (2015) Predictive Value of Age-Specific FSH Levels for IVF-ET Outcome in Women with Normal Ovarian Function. Reproductive Biology and Endocrinology, 13, 63. https://doi.org/10.1186/s12958-015-0056-6

[27] Orvieto, R., Meltzer, S., Robinson, J., Gerner, O., Anteby, E.Y. and Nahum, R. (2008) Does Day 3 Luteinizing Hormone Level Predict IVF Success in Patients Undergoing Controlled Ovarian Stimulation with GNRH Analogues. Fertility and Sterility, 90, 1297-1300. https://doi.org/10.1016/j.fertnstert.2007.10.058

[28] Regan, L., Owen, E.J. and Jacobs, H.S. (1990) Hyper Secretion of Luteinizing Hormone, Infertility, and Miscarriage. The Lancet, 336, 1141-1144. https://doi.org/10.1016/0140-6736(90)92765-A

[29] Reinthaller, A., Deutinger, J., Csaicsich, P., Riss, P., Muller-Tyl, E., Fischl, F. and Janisch, H. (1987) Effect of Serum Prolactin on Cycle Stimulation and Fertilization of Human Oocytes. Geburtshilfe und Frauenheilkunde, 47, 246-248. https://doi.org/10.1055/s-2008-1035816

[30] Ekwempu, C.C., Ekwempu, I.A., Adinoyi, A.D., Gofwen, D., Surajudeen, A.J. and Okonkwo, P.O. (2017) Relevance of Serum LH/FSH/Prolactin and Anti Mullerian Hormone Estimation in In-Vitro Fertilization. European Journal of Pharmaceutical and Medical Research, 4, 138-142.

[31] Liu, K. and Greenbalt, E. (2008) Elevated Day 3 Follicle Stimulating Hormone/Lut- 
einizing Hormone Ratio $>$ or $=2$ Is Associated with Higher Rates of Cancellation in In Vitro Fertilization, Embryo Transfer Cycles. Fertilization and Sterility, 90, 297-301. https://doi.org/10.1016/j.fertnstert.2007.06.038

[32] Barbakadze, L., Kristesashvili, J., Khonelidze, N. and Tsagareishvili, G. (2015) The Correlations of Anti-Mullerian Hormone, Follicle-Stimulating Hormone and Antral Follicle Count in Different Age Groups of Infertile Women. International Journal of Fertility and Sterility, 8, 393-398.

[33] Bala, J., Agrawal, Y., Seth, S., Goyal, V. and Kumar, P. (2014) Correlation between Anti-Müllerian and Follicle-Stimulating Hormone in Female Infertility. International Journal of Health \& Allied Sciences, 3, 232-236. https://doi.org/10.4103/2278-344X.143060

[34] de Vet, A., Laven, J.S., de Jong, F.H., Themmen, A.P. and Fauser, B.C. (2002) Antimullerian Hormone Serum Levels: A Putative Marker for Ovarian Aging. Fertility and Sterility, 77, 357-362. https://doi.org/10.1016/S0015-0282(01)02993-4

[35] Burger, H.G., Dudley, E.C., Hopper, J.L., Groome, N., Guthrie, J.R. and Green, A. (1999) Prospectively Measured Levels of Serum Follicle-Stimulating Hormone, Estradiol, and The dimeric Inhibins during the Menopausal Transition in a Population-Based Cohort of Women. The Journal of Clinical Endocrinology \& Metabolism, 84, 4025-4030. https://doi.org/10.1210/jcem.84.11.6158

[36] Jamil, Z., Fatima, S.S., Ahmed, K. and Malik, R. (2016) Anti-Mullerian Hormone. Above and Beyond Conventional Ovarian Reserve Markers. Disease Markers, 2016, Article ID: 5246217. https://doi.org/10.1155/2016/5246217

[37] Broekmans, F.J., Kwee, J., Hendriks, D.J., Mol, B.W. and Lambalk, C.B. (2006) A Systemic Review of Test Predicting Ovarian Reserve and IVF Outcome. Human Reproduction Update, 12, 685-618. https://doi.org/10.1093/humupd/dml034

[38] Majumdar, A. and Mangal, N.S. (2013) Hyperprolactinaemia. Journal of Human Reproductive Sciences, 6, 168-175. https://doi.org/10.4103/0974-1208.121400

[39] Mukhejee, T., Copperman, A.B., Lapinski, R., Sandler, B., Bustillo, M. and Grunfeld, L. (1996) An Elevated Day 3 Follicle Stimulating Hormone: Luteinizing Hormoneration (FSH:LH) in the Presence of a Normal Day 3 FSH Predicts a Poor Response to Controlled Ovarian Hyperstimulation. Fertility and Sterility, 65, 588-593. https://doi.org/10.1016/S0015-0282(16)58159-X

[40] Kofinas, J.D. and Elias, R.T. (2014) Follicle-Stimulating Hormone/Luteinizing Hormone Ratio as an Independent Predictor of Response to Controlled Ovarian Stimulation. Women's Health, 10, 505-509. https://doi.org/10.2217/WHE.14.31 